Original Research Article

\title{
Clinical and socio-demographic profile of treatment on osteoarthritis patients in Tirupathi, Andhra Pradesh, India
}

\author{
J. Viswanath ${ }^{1}$, Chakrapani Cheekavolu ${ }^{2 *}$, S. Sankaraiah ${ }^{3}$, Renu Dixit ${ }^{3}$
}

${ }^{1}$ Department of Dravyaguna, Sri Adi Siva Sadguru Allisaheb Sivaaryula Ayurvedic Medical College, Guntakal, Andhra Pradesh, India ${ }^{2}$ Department of Pharmacology, Kerala Medical College and hospital, Mangode, Palakkad, Kerala, India

${ }^{3}$ Department of Dravyaguna, S.V. Ayurcedic Medical College, Tirupathi, Andhra Predesh, India

Received: 04 June 2017

Revised: 23 June 2017

Accepted: 29 June 2017

\section{*Correspondence to:}

Dr. Chakrapani Cheekavolu, Email: chakri14783@gmail.com

Copyright: (C) the author(s), publisher and licensee Medip Academy. This is an openaccess article distributed under the terms of the Creative Commons Attribution NonCommercial License, which permits unrestricted noncommercial use, distribution, and reproduction in any medium, provided the original work is properly cited.

\begin{abstract}
Background: Osteoarthritis is a chronic degenerative joint disease and it is slowly progressive with signs and symptoms being pain. It is a common cause of disability affecting $60-70 \%$ of the population in the age of 60 years. It usually affects the hand, large weight bearing joints, often the knee and the hip.

Methods: A prospective study was carried out in S.V Ayurvedic Medical College and Hospital. Collected the data of Socio-demographic and risk factors (age, diet, history, marital status, religion, occupation etc.) during the treatment of osteoarthritis among the patients in hospital.

Results: The data reveals that majority of the patients belongs to the age group of 51-60 (43.33\%) and 41-50 years (33.33\%) followed by $61-70$ years $(16.66 \%)$, $31-40$ years $(6.66 \%)$, and $70 \%$ of females, $30 \%$ patients were Males in present study. $90 \%$ were married $10 \%$ were widows. $63.33 \%$ of Hindu, $23.33 \%$ were Muslims and only $13.33 \%$ were Christians. $40 \%$, of labour, $33.33 \%$ Businessmen, $13.33 \%$ Servicemen and $13.33 \%$ House wives. $53.33 \%$ rural, $46.66 \%$ urban area. $50 \%$ were belonging to middle class while $23.33 \%$ were very poor status, $16.66 \%$ Rich only $10 \%$ patients were from upper middle class families. $43.33 \%$ were Primary level education, $36.66 \%$ were illiterates, $10 \%$ up to Graduation, $6.66 \%$ Post-Graduation and $3.33 \%$ up to Matriculation. $63.33 \%$ mixed diet, $36.66 \%$ vegetarian.

Conclusions: Present study reveals that, incidence of osteoarthritis was very high especially in elder female, married, Hindu, labour, rural area, middle class with very poor, primary education, mixed diet (vegetarian with non-vegetarian) patients.
\end{abstract}

Keywords: Cissus quadrangularis linn, Demographic profile, Osteoarthritis, Tirupathi, Zingiber officinale rocs

\section{INTRODUCTION}

Osteoarthritis is one of the major public health problems especially in elder people. Osteoarthritis is a degenerative joint disorder with the symptoms of Joint Pain, Joint Swelling, Restricted and Painful Movements of the Joints and Joint Instability. It is a slow progressive disorder occurs usually after the age of 40 years. Defining osteoarthritis can be problematic. The condition may be considered a heterogenous group of joint disorders characterized pathologically by focal destruction of articulate cartilage, sub-chondral bone changes (including micro-fracture and cyst formation), and osteophyte formation. Osteoarthritis another name also called it as 'osteoarthritis or 'degenerative joint disease,' is the most common cause of arthritis. ${ }^{1} 100$ million people worldwide suffer from Osteoarthritis in Global population; it is also a one of the most common causes of eighth leading disability in 
osteoarthritis. ${ }^{2}$ Prevalence of Knee Osteoarthritis increases elder women's, approximately $11 \%$ of women suffering from knee Osteoarthritis over the age of 60 years. Most of the knee Osteoarthritis treated by general physicians rather than rheumatologists. ${ }^{3}$ Age is the most powerful riskfactor in osteoarthritis. ${ }^{4}$ The prevalence of knee OA was very high in aged people. ${ }^{5}$ Earlier studies shows that the prevalence of osteoarthritis between the ages of 30 to 65 years. Men are affected more often than women among those aged 55 years. ${ }^{6}$

\section{METHODS}

The present study evaluation of clinically based prospective and it was carried out in S.V Ayurvedic Medical College and hospital, Tirupathi, Andhra Pradesh in the period from Jan 2014 Dec 2015.

All the patients were followed up at interval of 15 days. Total duration of treatment was 3 months. Collected data of Socio-demographic and risk factors of osteoarthritis among patients in hospital (age, diet, Marital status, religion, occupational etc.,).

\section{Study design}

\section{Selection of patients}

Present study consists of 71 cases of osteoarthritis patients selected from the Department of Dravyaguna of T.T.D's S.V. Ayurvedic Hospital, Tirupati. Out of these 71 patients, 11 cases did not turn up for follow up, thus the present study population include only 60 patients. According to treatment schedule patients were divided into 3 Groups: Group A; treatment of Cissus quadrangularis linn, Group B; treatment of Zingiber officinale rocs, Group $\mathrm{C}$; treatment of Cissus quadrangularis linn combined with Zingiber officinale rosc. For osteoarthritis.

\section{Inclusion criteria}

- Patient's age group of 31-70 years was selected.

- Patient with osteoporosis and osteophytic changes.

- Obese patients.

- Patients with history of Trauma.

- Patients with Endocrine disorders mainly menopausal women.

\section{Exclusive criteria}

- Patients age below 31 and above 70 years.

- Patients suffering from Carcinoma and psoriatic arthritis.

- Patients suffering from Ankolysing arthritis.

- Patients suffering from Poliomyalgia and Rheumatoid arthritis.

- Patients suffering from Tuberculosis.

- Patients suffering from Syphilitic arthritis.

\section{RESULTS}

Patients between the age group of 30-70 years were selected for the present clinical study. The data reveals that majority of the patients belongs to the age group of 51-60 $(43.33 \%)$ and $41-50$ years $(33.33 \%)$ followed by $61-$ 70 years $(16.66 \%)$, and $31-40$ years $(6.66 \%)$. This shows that osteoarthritis is more common in the age group of 5160 years (Table 1 ).

Table 1: Distribution of patients according to age.

\begin{tabular}{|llll|ll|}
$\begin{array}{l}\text { Age } \\
\text { in } \\
\text { years }\end{array}$ & $\begin{array}{l}\text { Go. of patients } \\
\text { A }\end{array}$ & $\begin{array}{l}\text { Group- } \\
\text { B }\end{array}$ & $\begin{array}{l}\text { Group- } \\
\text { C }\end{array}$ & Total & $\%$ \\
\hline $31-40$ & 2 & 0 & 2 & 4 & 6.66 \\
\hline $41-50$ & 6 & 8 & 6 & 20 & 33.33 \\
\hline $51-60$ & 8 & 10 & 8 & 26 & 43.33 \\
\hline $61-70$ & 4 & 2 & 4 & 10 & 16.66 \\
\hline Total & 20 & 20 & 20 & 60 & 100 \\
\hline
\end{tabular}

In the present study, maximum number of Patients i.e. 70 $\%$ were of Females and remaining $30 \%$ patients were Males (Table 2).

Table 2: Distribution of patients according to sex.

\begin{tabular}{|lllllll|}
\hline Sex & $\begin{array}{l}\text { No. of patients } \\
\text { Group- }\end{array}$ & $\begin{array}{l}\text { Group- } \\
\text { A }\end{array}$ & B & $\begin{array}{l}\text { Group- } \\
\text { C }\end{array}$ & Total & $\%$ \\
\hline Male & 8 & 4 & 6 & 18 & 30 \\
\hline Female & 12 & 16 & 14 & 42 & 70 \\
\hline Total & 20 & 20 & 20 & 60 & 100 \\
\hline
\end{tabular}

As evident from the table, majority of cases were married (90\%) and remaining $10 \%$ were widows (Table 3 ).

\section{Table 3: Distribution of patients according to marital status.}

\begin{tabular}{|c|c|c|c|c|c|}
\hline \multirow[b]{2}{*}{$\begin{array}{l}\text { Marital } \\
\text { status }\end{array}$} & \multicolumn{3}{|c|}{ No. of patients } & \multirow[b]{2}{*}{ Total } & \multirow[b]{2}{*}{$\%$} \\
\hline & $\begin{array}{l}\text { Group- } \\
\text { A }\end{array}$ & $\begin{array}{l}\text { Group- } \\
\text { B }\end{array}$ & $\begin{array}{l}\text { Group- } \\
\text { C }\end{array}$ & & \\
\hline Single & 0 & 0 & 0 & 0 & 0 \\
\hline Married & 16 & 18 & 20 & 54 & 90 \\
\hline Widow & 4 & 2 & 0 & 6 & 10 \\
\hline Widower & 0 & 0 & 0 & 0 & 0 \\
\hline Total & 20 & 20 & 20 & 60 & 100 \\
\hline
\end{tabular}

In this study Labour were more in number i.e. $40 \%$, followed by Businessmen (33.33\%), Servicemen (13.33\%) and House wives (13.33\%). This shows Osteoarthritis is more common in Labour class. (Table 4).

Table shows that maximum i.e. $50 \%$ patients were belonging to Middle class while $23.33 \%$ were from very poor status, and $16.66 \%$ patients were belonged to Rich 
only $10 \%$ patients were from Upper middle class families (Table 5).

Table 4: Distribution of patients according to occupation.

\begin{tabular}{|c|c|c|c|c|c|}
\hline \multirow[b]{2}{*}{ Occupation } & \multicolumn{3}{|c|}{ No. of patients } & \multirow[b]{2}{*}{ Total } & \multirow[b]{2}{*}{$\%$} \\
\hline & $\begin{array}{l}\text { Group } \\
-A\end{array}$ & $\begin{array}{l}\text { Group- } \\
\text { B }\end{array}$ & $\begin{array}{l}\text { Group- } \\
\text { C }\end{array}$ & & \\
\hline Housewife & 4 & 2 & 2 & 8 & 13.33 \\
\hline Labour & 8 & 10 & 6 & 24 & 40 \\
\hline Business & 6 & 6 & 8 & 20 & 33.33 \\
\hline Service & 2 & 2 & 4 & 8 & 13.33 \\
\hline Total & 20 & 20 & 20 & 60 & 100 \\
\hline
\end{tabular}

Table 5: Distribution of patients according to socioeconomic status.

\begin{tabular}{|llllll|}
\hline $\begin{array}{l}\text { Socio- } \\
\text { economic } \\
\text { status }\end{array}$ & $\begin{array}{l}\text { No. of patients } \\
\text { Group- }\end{array}$ & $\begin{array}{l}\text { Group- } \\
\text { B }\end{array}$ & $\begin{array}{l}\text { Group- } \\
\text { C }\end{array}$ & Total & $\%$ \\
\hline $\begin{array}{l}\text { Very } \\
\text { poor }\end{array}$ & 6 & 2 & 6 & 14 & 23.33 \\
\hline Middle & 10 & 12 & 8 & 30 & 50 \\
\hline $\begin{array}{l}\text { Upper } \\
\text { middle }\end{array}$ & 0 & 4 & 2 & 6 & 10 \\
\hline Rich & 4 & 2 & 4 & 10 & 16.66 \\
\hline Total & 20 & 20 & 20 & 60 & 100 \\
\hline
\end{tabular}

As shown in table, maximum number of Patients i.e. 43.33 $\%$ were having the education upto the Primary level followed by $36.66 \%$ patients were illiterates, $10 \%$ of Patients were having education up to Graduation, $6.66 \%$ patients had completed their Post-Graduation and 3.33\% patients were having education up to Matriculation (Table $6)$.

Table 6: Distribution of patients according to education wise.

\begin{tabular}{|c|c|c|c|c|c|}
\hline \multirow[b]{2}{*}{ Education } & \multicolumn{3}{|c|}{ No. of patients } & \multirow[b]{2}{*}{ Total } & \multirow[b]{2}{*}{$\%$} \\
\hline & $\begin{array}{l}\text { Group- } \\
\text { A }\end{array}$ & $\begin{array}{l}\text { Group- } \\
\text { B }\end{array}$ & $\begin{array}{l}\text { Group- } \\
\text { C }\end{array}$ & & \\
\hline Illiterate & 6 & 12 & 4 & 22 & 36.66 \\
\hline Primary & 12 & 4 & 10 & 26 & 43.33 \\
\hline Matriculation & 2 & 0 & 0 & 2 & 3.33 \\
\hline Graduation & 0 & 4 & 2 & 6 & 10 \\
\hline Post graduate & 0 & 0 & 4 & 4 & 6.66 \\
\hline Total & 20 & 20 & 20 & 60 & 100 \\
\hline
\end{tabular}

It is evident from the Figure 1 that majority of cases were Hindu (63.33\%) while remaining patients i.e. $23.33 \%$ were Muslims and only $13.33 \%$ were Christians.

Figure 2 shows that majority of cases belonged to Rural area $(53.33 \%)$ followed by urban area $(46.66 \%)$. It is clear from Figure 3 that maximum patients were taking mixed diet $(63.33 \%)$, followed by vegetarian $(36.66 \%)$.

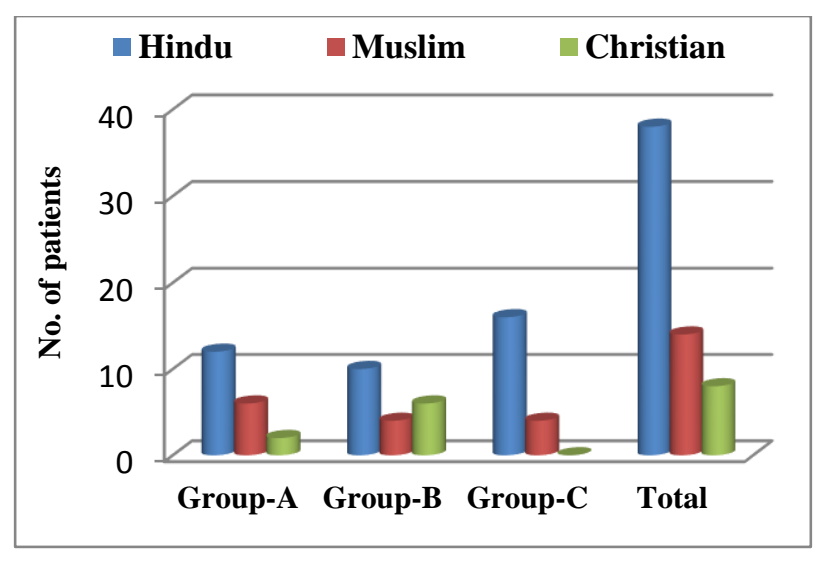

Figure 1: Distribution of patients according to religion.

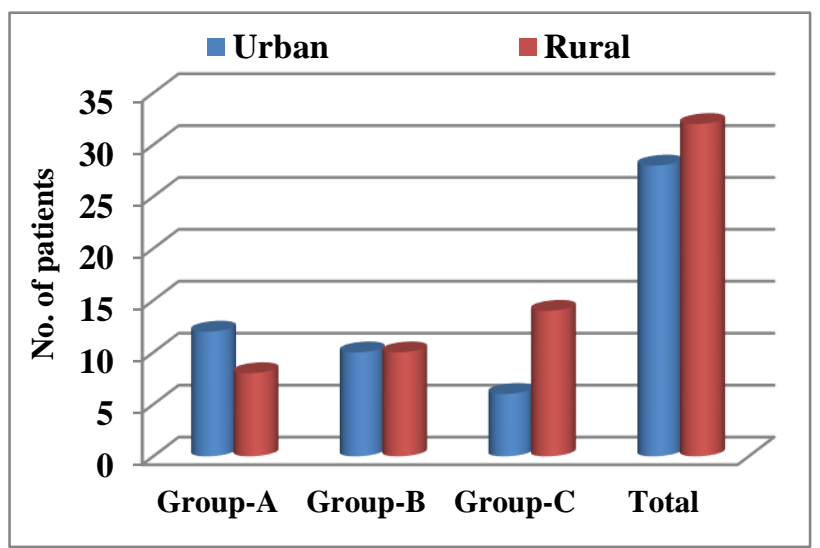

Figure 2: Distribution of patients according to habitat.

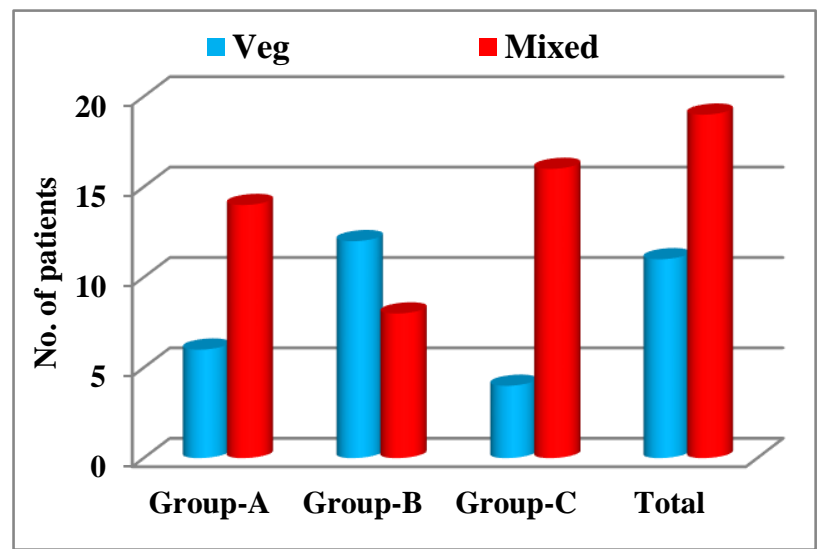

Figure 3: distribution of patients according to dietary habit.

\section{DISCUSSION}

Osteoarthritis is a chronic degenerative joint disease especially in the older age, usual signs and symptoms being pain, enlarged and deformed joints. It is a most common cause of disability affecting nearly $60-70 \%$ of the population in the older age people with the age of 60 years. It usually affects the hand and large weight bearing joints, often the knee and the hip. ${ }^{7}$ In the global population prevalence for sign and symptomatic osteoarthritis is $9.6 \%$ 
men and $18 \%$ in women. In the earlier studies says that, risk factors in high risk population include female gender, old age, overweight, history of previous injuries or surgeries on the knee. ${ }^{8-10}$ Among females, the incidence of osteoarthritis was high especially during menopausal age period. Several studies have been says to loss or less of oestrogen at the time of menopause increases the women's risk of getting osteoarthritis. The prevalence and the distribution pattern of the osteoarthritis disease vary common depending on the geographical distribution. A clinically hospital based study was carried out with a purpose to assess the socio demographic and risk factors of osteoarthritis among the study population.

\section{CONCLUSION}

Present study reveals that, the incidence of osteoarthritis was very high especially in elder female, married, Hindu, labour, rural area, middle class with very poor, primary education, mixed diet (vegetarian with non-vegetarian) patients.

Funding: No funding sources Conflict of interest: None declared

Ethical approval: The study was approved by the Institutional Ethics Committee

\section{REFERENCES}

1. Kelsey JL, Hochberg MC. Epidemiology of chronic musculoskeletal disorders. Annu Rev Public Health, 1988;9:379-401.

2. Hinman RS, Hunt MA, Creaby MW, Wrigley T, McManus FJ, Bennell KL. Hip muscle weakness in individuals with medial knee osteoarthritis. Arthritis Care Res. 2010;62:1190-3.

3. Creamer P, Lethbridge Cejku M, Hochberg MC. Factors associated with functional impairment in symptomatic knee osteoarthritis. Rheumatology. 2000;39(5):490-6. [Cited November 23, 1999].

4. Cicuttini FM, Spector TD. Evidence for the increasing prevalence of osteoarthritis with aging; does this pertain to the oldest old? In Osteoarthritis - public health implications for an aging population (ed. D Hamerman). Baltimore, MD: The Johns Hopkins University Press; 1997:49-62.

5. Maurer K. Basic data on arthritis knee, hip, and sacroiliac joints in adults ages, 25-74 years. Vital and Health Statistics - Series 11: Data from the National Health Survey. 1979;213:1-31.

6. Bhatia D. Current interventions in the management of Knee Osteoarthritis. Journal of Pharmacy and Bio Allied Sciences. 2013;5(1).

7. Nevitt MC, Felson DT, Gayle L. Osteoarthritis initiative- Protocol for Cohort Study. Available at: http://oai.epiucsf.org/datarelease/docs/StudyDesignPr otocol.pdf.

8. Felson DT, Zhang Y. An update on the epidemiology of knee and hip osteoarthritis with a view to prevention. Arthritis Rheum. 1998;41(8):1343-55.

9. Felson DT, Chaisson CE. Understanding the relationship between body weight and osteoarthritis. Baillieres Clin Rheum. 1997;11(4):671-81.

10. Oliveria SA, Felson DT, Cirillo PA, Reed JI, Walker AM. Body weight, body mass index, and incident symptomatic osteoarthritis of the hand, hip, and knee. Epidemiology. 1999 Mar 1:161-6.

Cite this article as: Viswanath $\mathrm{J}$, Chakrapani $\mathrm{CH}$, Sankaraiah S, Dixit R. Clinical and sociodemographic profile of treatment on osteoarthritis patients in Tirupathi, Andhra Pradesh, India. Int J Basic Clin Pharmacol 2017;6:2010-3. 